\title{
A STUDY OF NOVELTY-SEEKING-BASED REVISITING INTEREST AT KETEP PASS TOURISM OBJECT IN MAGELANG REGENCY
}

\author{
Endang Swastuti \\ Universitas 17 Agustus 1945 Semarang \\ diponegoro217@yahoo.com \\ Emiliana Sri Pudjiarti \\ Universitas 17 Agustus 1945 Semarang \\ emilpujiarti@gmail.com
}

\begin{abstract}
The purpose of this study was to identify a model of relationship between novelty seeking based tourism, service quality and destination image toward tourists' satisfaction and tourists' revisiting in the Ketep Pass area of Magelang Regency. Data collection used a survey through questionnaires, observation and interviews of 249 domestic and foreign tourists with purposive sampling technique. Data were analyzed by structural equation model to test the hypothesis. The results of the study prove that novelty seeking based tourist attraction, service quality and destination image give significant influence on tourists' satisfaction and revisiting. This condition explains that the diversity of potential tourist attractions in the Magelang Regency Ketep Pass area can be developed as a new tourist destination (novel atraction) on the Solo-SeloBorobudur (SSB) route with the characteristic of the mountain tourism namely Mount Merapi. This new tourist attraction is able to provide meaningful benefits for tourists in the form of enrichment values, self-development, challenge or adventure, as well as new knowledge or insight even though sometimes full of risks.
\end{abstract}

Keywords: Novelty Seeking Based Tourist Attraction; service quality; satisfaction; destination image; revisiting

JEL Classification: L83

\section{INTRODUCTION}

Based on economy aspect, Magelang Regency establishes three preminent areas: agriculture, Small and Medium Scale Industry (UMKM), and tourism. According to Magelang Tourism Master Plan, there are about 60 tourist destinations in Magelang Regency. One of the main tourism destination is Ketep Pass Region. it is strategically situated to be functioned as nature tourism due to its 5 mountain views with all its uniqueness. The diversity of tourism potential in this region is able to attract domestic and foreign tourists.
Ketep Pass tourist area can be developed as a new tourist destination (novel atraction) on the Solo-Selo-Borobudur (SSB) route with the characteristic of mountain tourism, namely Mount Merapi. Based on marketing management aspect, tourism products are not a real product. Since, this product is a series of service that do not only involve economic, factor but also social, psychological and natural factor. Despite tourism products themselves are largely influenced by economic behavior. According to (Witt et al., 1994) the attraction of tourist destinations is the main motivation for tourists to make tourist visits. As mentioned by 
Schiffman (Schiffman and Kanuk, 2007) that in determining the quality of services by consumers must be based on the attributes which are associated with the product.

In carrying out a tour, the tourists will not only see or visit tourist destinations with a variety of attractions and events, but also they rather emphasize the wealth of experience gained through involvement in an activity. The implication of this tendency is the increasingly attractive types of tourism products that emphasize the elements of experience extraction, insight and knowledge in the form of active involvement in a particular type of activity in tourist destinations.

According to (Weiler et al., 1992) these tourist destinations are based on novelty seeking, namely motivation on the search for unique and new tourist attractions, or exploration of new, more challenging and interesting tourism. This new tourist attraction is able to provide meaningful benefits for tourists in the form of values of enrichment or self-development, value of challenges or adventure, as well as the value of new knowledge or insight even though sometimes full of risks. Quality in the tourism industry must be competitive, so service quality is identified as a key factor in maintaining the competitiveness of tourist destinations. In addition, good service quality is not only intended to satisfy tourists but also improves destination image, which differs from other destinations so that it is able to build tourist loyalty to revisit. Previous research on customer loyalty generally emphasized efforts to analyze factors that influence customer satisfaction such as (Zeithaml and Bitner, 2009). However, several other studies revealed that customer satisfaction did not always have a linear relationship to revisit (Söderlund and Öhman, 2003). Yoeti (2008) explained that groups of companies that directly provided services to tourists when they came to visit a tourist place would provide comfort, security and satisfaction in seeking the desired pleasure.

Furthermore, to improve tourism marketing, image is also an important factor in influencing demand. Based on this point of view, the image which consists of objective enlightenment, impressions, prejudices, dreams, hopes, emotions and thoughts, determine travelers to choose the desired destination. The findings (San Martín and Rodríguez, 2008) of tourist image on tourist destinations are subjective because they are based on their respective perceptions of destinations that have been visited or known. In other words, the image of a tourist destination is evaluated through attributes of resources and attractions. This attribute is motivating to travel (Assaker et al., 2011).

According to (Bigne et al., 2007; Lin et al., 2003) important variables in enhancing the competitiveness of the tourism industry are tourism attraction, facilities, infrastructure, sustainability, environment and image enhancement of tourist destinations. The problem is that the quality of the tourism area (which is tangible) of the SSB pathway has not been conceptually arranged, whereas it can be a novelty atraction. Activities and attractions around the area are: geophysical attractions (volcanic phenomenon with hot-cold lava bursts; florafauna diversity; peak crater; biotic attractions (Kinahrejo-Tlogomuncar Tracking Track; Tlogo Putri; Kaliurang arboretum; Turgo hill; Plawangan hill; attractions 
community forest agroforestry pattern) Attractions abiotis (BoyongKaliurang Barat river; sand or rock excavation in Boyiran River); sociocultural attractions (traditional village Turgo; trust G Merapi; Mount Merapi disaster-Keraton-Queen of the South Sea, etc. ) Based on these matters, the purpose of this study is focused on developing a model for developing interest in revisiting based on novelty, and the empirical problem is: "How does the relationship between novelty seeking based tourist attraction, service quality and destination image, satisfaction and interest in revisiting tourists at Magelang Regency Ketep Pass Area".

\section{LITERATURE REVIEW}

\section{Quality of Travel Destination Services}

There are many definitions of service quality, yet generally those have similarities. It is called servqual, a quality service model that is widely used in marketing services and marketing research (Zeithaml et al., 1996). The servqual model was developed to help managers understand the right ways to improve service quality.

The servqual model consists of five basic components, namely: reliability, tangibility, assurance, empathy and responsiveness. Service quality is defined as the consumer's assessment of all product advantages (Zeithaml and Bitner, 2009). Many researchers measure the quality of services based on customer perceptions of the services they consume (Zeithaml and Bitner, 2009). Perception in evaluating the quality of services depends on the gap between the expected and received results.

\section{Travel Destination Image}

To improve tourism marketing, image is an important factor to influence the demand. Based on this point of view, the image consists of objective enlightenment, impressions, prejudices, dreams, hopes, emotions and thoughts that determine tourists to choose their vacation destinations. Lawson and Baud Bovy (1977) define the image of a tourist destination as an expression of all objective knowledge, imagination and emotional person or group about a particular tourist location. Crompton (1979) defines image as an overall belief, idea and impression that someone associates with a tourist destination. Bigne et al. (2001) defines the image of tourism as a subjective interpretation of reality by tourists. Tourist destinations can take the form of active activities such as: walking, playing, exercising, chatting, but also passive activities: sitting, seeing, reflecting, prayingmeditation, both of which will be distinguished in its architectural design and spatial layout.

Rajesh (2013) explaines that destination image consists of cognitive image and affective image of destination. Cognitive images are beliefs and information that a person has about a destination (Rajesh, 2013). The dimensions of cognitive imagery include touristy traditions, basic facilities, cultural attractions, accessibility and tourism substructure (touristy substructures and access), natural environment, and economic factors (variety and economical factors). While the affective image according to (Artuğer et al., 2013) is an image related to the emotions or feelings of tourists regarding a destination.

\section{Tourists' Overall Satisfaction}


Zeithaml and Bitner (2009) state that satisfaction is a consumer response to perceive service quality, and is a cognitive response to the services offered. While overall satisfaction is an emotional response based on the overall phenomenon of view. This opinion is in line with (Baker and Crompton, 2000) which defines tourist satisfaction as an emotional state of tourists after traveling. The theory of confirmation and disconfirmation defines satisfaction as a postpurchase evaluation in the decision to make a purchase. Satisfaction measurement according to Coban (2012) is described as an evaluation of the quality of tourism destination performance as what is felt in a tourism destination, whether the destination is pleasant or unpleasant.

\section{Novelty Seeking Based Tourism Attraction}

Zuckerman and Kuhlman (2000) describe that novelty needs are the need to find something new and unique in traveling. According to (Assaker et al., 2011), novelty seeking is a level of difference in current perceptions with past experience in traveling so that it has a new goal in the next trip. While (Feng and Jang, 2004) explained that novelty seeking in tourism activities is an activity or an attempt to find something new to visit or travel to an object or tourist attraction.

The concept of novelty seeking is a motivation to find new and unique tourist objects and attractions, or explore new, more challenging locations. People who have a novelty seeking tendency, will tend to explore themselves in new and impulsive situations, make decisions quickly without much consideration of the consequences, ready to spend their money in order to fulfill their desires, and tend to be spontaneous in behaving and disliking many rules. The need for novelty is influenced by sensation seeking trait in tourists. Individuals with high sensation seeking traits, have high stimulus and arousal needs so that they tend to behave in a risky manner and want to find sensations, challenges, new experiences, and variations in the life of sensation seeking trait. It is a nature of seeking "sensations" in individuals driven by the need to seek variation, novelity, complex sensations and experience, which is accompanied by a desire to take physical, legal, financial and social actions that are risky in order to gain experience (Zuckerman and Kuhlman, 2000).

\section{Revisiting}

According to Kinnear, (Kinnear et al., 2003) buying interest, is defined as a tendential stage of the trespondents to act before making a purchase decision. After the consumer makes a purchase decision, he feel satisfied after consuming the product at the next stage. A consumer's satisfaction will foster loyal behavior, and have a commitment to the product, which in the end will generate interest in re-buying the product in the future. Artuğer et al. (2013) describe two determinants of loyalty in tourism destinations. First, intention to revisit the destination which means that tourists show their loyalty by revisiting related tourism destinations in the future. Second, giving positive feedbacks about the destination and recommendations to others. It means that tourists show their loyalty by saying positive things about tourism destinations then recommend the tourism destination to others.

\section{Research Hypothesis Development}

Customer satisfaction is one of the goals to be achieved in 
marketing, because if the customer feels satisfied with the product they buy, then the customer will make a repeat purchase and will disseminate the information to others. The satisfaction of a product that is purchased by consumers, will provide experience for consumers, so that it will give a positive impression on the product they buy. This positive impression in the minds of consumers will make it easier for consumers to make purchasing decisions. Experience is something that is very important to be done by a marketer, because it can be used as a tool to improve competitiveness, as well as experiential tourism. Therefore, customer satisfaction is a very interesting concept in service marketing because there is correlation between post-purchase and consumption satisfaction that impacts attitudes, repurchase, word-of-mouth (Fornell et al., 1996).

Service research often tests the relationship between service quality and satisfaction (Zeithaml et al., 1996) and the relationship between satisfaction and purchase intention in the future (McDougall and Levesque, 2000). Thus satisfaction is seen as mediating the relationship between attitude towards quality and repurchase intention (Kozak, 2000). Similarly, Bosque and Martin (2008) found that tourist satisfaction is shaped by previous attitudes and beliefs, post-experience assessments, and behavioral intentions in the future. The results of his research also observed that the image has a significant role in loyalty even though the relationship is not direct, but through satisfaction of the results of the visit. Bolton and Drew (1991) provide empirical support for the relationship between quality and perceived value. Their findings indicate that perceived service quality explains most of the variance in service value, and perceived value is a good measurement of the overall evaluation by tourists due to the perceived service quality. Tian-Cole et al. (2002) also stated that perceptions of service quality and satisfaction have proven to be good predictors of visitors' future behavioral intention. Based on the above description, the three hypotheses proposed are as follows:

$\mathrm{H} 1$ : The higher the quality of service, the higher the satisfaction of tourists.

$\mathrm{H} 2$ : The higher the image of tourism products, the higher the satisfaction of tourists.

H3: The higher the quality of service, the higher the interest in revisiting.

Mahasuweerachai et al (2011) suggest that perceived service quality is a cognitive response to the services offered, while overall satisfaction is an emotional response based on the overall phenomenon of view. Another different study is that the research proposes a more comprehensive framework for the intention to revisit models on tourist destinations. According to him, in addition to perception of quality and satisfaction as explanatory variables and revisiting nterest, it was proven as a variable that was explained as well as the image destination variable because it had an important role to be considered and chosen in the travel decision making process (Prayag and Ryan, 2011; Yoon and Uysal, 2005) .

A package attribute of tourist destinations according to Middleton (1995) are: natural attraction; building attraction; managed visitor attractions; and cultural attraction is the total attraction of tourism products including tangible and intangible components, which are used for activities at tourist 
destinations. The package is perceived by tourists as a total experience that can be purchased at a certain price. According to (Gunn and Mercer, 2009), the formation of images before the trip is the most important phase in the process of selecting tourist destinations.

$\mathrm{H} 4$ : The higher the quality of service, the better the novelty seeking based tourism attraction.

H5: The higher the quality of service, the higher the image of Tourism Products.

H6: The higher the image of tourism products, the higher the interest in revisiting.

H7: The higher the tourist satisfaction, the greater the interest in revisiting.

While the perceived image after a tourist visit will affect satisfaction and intensity to make a return visit in the future, this depends on the ability of the tourist destination in providing tourist attraction that can provide a pleasant experience in accordance with the wishes and needs of tourists on the way travel. Coban (2012) proves in his research that a positive destination image will make tourists feel better satisfaction, and tourists who positively value the image of a destination may be willing to revisit and recommend destinations related to others. Artuğer et al. (2013) explain that destination image influences tourist behavior such as intending to revisit and recommend it to others. Artuğer et al. (2013) also proves that there is a strong and positive relationship between the image of a destination and a destination. They show that cognitive image has a greater influence on loyalty than affective image. So, it can be concluded that the behavior of future travelers who positively assess tourism destinations is likely to revisit and recommend to others.

H8: The higher the novelty seeking based tourist attraction, the higher the tourists' satisfaction.

Thus in general it can be interpreted that the quality or quality of tourism products is a series of various interrelated services-which are produced from various companies (in terms of economics), community services (in terms of social) and natural services, whose presentation is in accordance with the applicable sizes on tourism products and services to meet the needs, desires and expectations of tourists. The results of the study (Bigne et al., 2001) conclude that the quality of tourist attraction diversity influences tourists to revisit.

The tourists are now increasingly critical in choosing the locations to be visited as tourist destinations, because in their travels, tourists are no longer aim to see or visit many tourist destinations with a lot of attractions, but rather emphasize the wealth of experience gained through their involvement in an activity and do something to gain valuable experience for selfdevelopment (Parikesit and Hernowo 1997). According to motivation theory, tourists do not just want to fulfill physical needs, but it has turned to self-development motivation and even selfactualization. Thus, the behavior patterns of tourists in traveling are very diverse. One form of tourist behavior patterns in travel is novelty seeking. Many experts examine novelty seeking that relates to new experiences where the level of novelty becomes a function of discrepancy between past experience and the present. The dissatisfaction felt in past experiences or previous travels becomes a benchmark for finding 
new things to obtain tourist satisfaction. Novelty-seeking is an important component in travelling motivation (Crompton, 1979), and also as an antecedent of loyalty and interest in revisiting (Assaker et al., 2011).

H9: The higher the novel seekingbased tourist attraction, the higher the interest in revisiting.

\section{RESEARCH MODEL}

Based on the above reason, the following chart (chart 1) shows hypothetical model of this study about novelty seeking based revisiting interest.

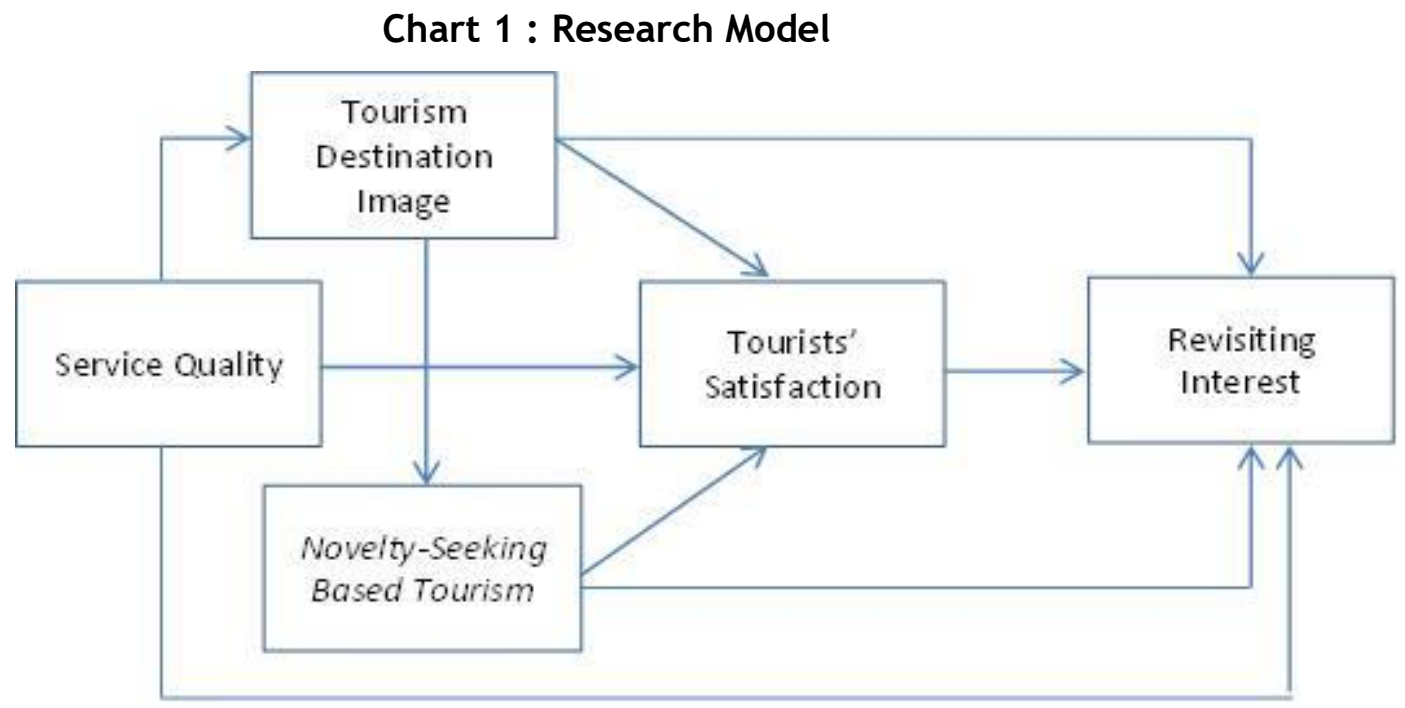

$\mathrm{H} 1$ : The higher the quality of service, the higher the satisfaction of tourists.

$\mathrm{H} 2$ : The higher the image of tourism products, the higher the satisfaction of tourists.

H3: The higher the quality of service, the higher the interest in revisiting.

H4: The higher the quality of service, the better the novelty seeking based tourism attraction.

H5: The higher the quality of service, the higher the image of Tourism Products.
H6: The higher the image of tourism products, the higher the interest in revisiting.

H7: The higher the tourist satisfaction, the greater the interest in revisiting.

H8: The higher the novelty seeking based tourist attraction, the higher the tourists' satisfaction.

H9: The higher the novel seekingbased tourist attraction, the higher the interest in revisiting.

Table 1 : Concept Definition and Variables Operation

\begin{tabular}{|c|c|}
\hline Variable and Definition & Indicators \\
\hline $\begin{array}{l}\text { 1. Novel-seeking tourist-based } \\
\text { attractions: } \\
\text { It is a motivation to look for new } \\
\text { and unique tourist attractions, or } \\
\text { explore new, more challenging } \\
\text { locations. (Assaker et ael., 2011). }\end{array}$ & $\begin{array}{l}\text { a. Even sensational challenges and risks } \\
\text { b. Related to new and unique things } \\
\text { c. Un-usual stimulus or surprise } \\
\text { d. New attraction and event } \\
\text { e. New natural scenery }\end{array}$ \\
\hline
\end{tabular}




\begin{tabular}{|c|c|}
\hline Variable and Definition & Indicators \\
\hline $\begin{array}{l}\text { 2. Service Quality: } \\
\text { The rating of tourists on all the } \\
\text { benefits of tourism services that } \\
\text { meet the expectations of tourists. }\end{array}$ & $\begin{array}{l}\text { a. Hospitality } \\
\text { b. Responsive } \\
\text { c. Reliability } \\
\text { d. Responsibility } \\
\text { e. Tangibility }\end{array}$ \\
\hline $\begin{array}{l}\text { 3. Tourism Product Image : } \\
\text { Subjective interpretation of reality } \\
\text { in the form of overall beliefs, ideas } \\
\text { and impressions, expressions of all } \\
\text { objective knowledge, imagination } \\
\text { and emotionality of a person or } \\
\text { group about a tourist location } \\
\text { (Bigne et al., 2001; Crompton, } \\
\text { 1979). }\end{array}$ & $\begin{array}{l}\text { a. Product is easy to know (Friendly) } \\
\text { b. Authenticity in nature (Naturally) } \\
\text { c. Familiar with the minds of consumers } \\
\text { (popular) } \\
\text { d. Accessibility } \\
\text { e. Uniqueness and distinctiveness }\end{array}$ \\
\hline $\begin{array}{l}\text { 4. Tourists' Satisfaction : } \\
\text { The cognitive situation of the buyer } \\
\text { which is related to the equivalence } \\
\text { between the results and the } \\
\text { sacrifices made. (Baker \& } \\
\text { Crompton, 2000). }\end{array}$ & $\begin{array}{l}\text { a. Travel experience } \\
\text { b. Value of perceived satisfaction } \\
\text { c. Memory as a whole }\end{array}$ \\
\hline $\begin{array}{l}\text { 5. Revisiting Interest: } \\
\text { Tourist behavior responds positively } \\
\text { to the quality of service for tourist } \\
\text { attraction and revisiting interest. } \\
\text { (Artuğer et al., 2013; Kinnear et al., } \\
\text { 2003). }\end{array}$ & $\begin{array}{l}\text { a. Say positive things } \\
\text { b. Reffer visits } \\
\text { c. Visit preferences }\end{array}$ \\
\hline
\end{tabular}

\section{METHOD, DATA, AND ANALYSIS}

The population of this study were visitors of Ketep Pass in Magelang Regency. Research samples were 249 respondents. The technique used in thisi study was purposive sampling technique. The criteria were domestic or foreign tourists who had visited at least twice and aged 15 years and above. The data were collected through questionnaires and interviews and were analyzed using structural equation model (SEM). There are at least five stages of in SEM, they are (1) Model Conceptualization, (2) Alogarithm Analysis Method, (3) Path Diagram, (4) Model Evaluation and (5) interpretation (Ghozali \& Laten, 2012). All variables (service quality, tourist image, tourist attraction, tourist satisfaction and revisiting interest) were estimated using convergent validity with loading values $>0.50$.

Table 2: AVE Values

\begin{tabular}{lc}
\hline \multicolumn{1}{c}{ Variables } & Average variances Extracted (AVE) \\
\hline Service Quality & 0,520 \\
Tourist Image & 0,584 \\
Tourist attraction & 0,569 \\
Tourist satisfaction & 0,756 \\
\hline
\end{tabular}




\begin{tabular}{cc}
\hline Revisiting interest & 0,659 \\
\hline Source : Processed Primary Data, 2018
\end{tabular}

\section{RESULT AND DISCUSSION}

\section{Description Of Ketep Pass Tourism Destination In Magelang District}

Magelang Regency is
geographically a strategically
located on the provincial route.
Magelang is developing three
prominent fields; agriculture, Small
and Medium Scale Industry (UMKM),
and tourism. According to the master
plan, Magelang Regency has
approximately 60 tourism
attractions. One of the outstanding tourist objects is Ketep Pass which is located in Ketep Village, Sawangan District. Ketep Pass is a natural tourism object that is developed with the characteristic of mountain tourism, that is Mount Merapi. The mountain is located at an altitude of 1200 meters above sea level and the area is approximately 8000 square meters. Ketep Pass tourism object is functioned as documentation, demonstration, and education with the existence of Volcano Center and Volcano Theater, and research purpose. Meanwhile, Mount Merapi destination has recreation purpose by optimazing the viewing post and Panca Arga yard.

Several Ketep Pass facilities are; (1) Volcanology Museum. This museum has an area of approximately 550 square meters. Inside the museum, it stands a miniature of Mount Merapi, an interactive computer that contains documents on the volcano, several examples of rocks evidence of eruptions from year to year, posters of a $3 \times 3 \mathrm{~m}$ Garuda peak, a poster of Mount Merapi's early warning, and also some photos and posters depicting the story from the activities of Mount Merapi. (2). Mini cinema: it has 78 seats. This cinema presents a documentary movie film about the history of Mount Merapi which includes events of the formation, climbing routes, research at the peak of Garuda, the massive eruption of Mount Merapi, and various events that occurred in a certain time series. The movie take 25 minutes long. (3) Telescope: There are two telescopes in Ketep Pass. Those two telescopes are at the top of Panca Arga and Gardu Pandang. With this tool, visitors can clearly see the beauty of Mount Merapi scenery, Merbabu and other mountains. (4). Panca Arga courting: which means five mountains. This location is the highest peak in Ketep Pass Tourism Object. From this highest peak visitors can see 5 mountains, namely Merapi, Merbabu, Sindoro, Sumbing, and Slamet. In addition to the five mountains, visitors can also see and enjoy small mountains and very beautiful hills, including Mount Tidar, Mount Andong, Pring Mountain, Menoreh Hill,Telomoyo Hill, and others. (5) Gardu Pandang (viewing gazebo), is two gazebos with a rectangular size and an octagonal building with a five meters in length. From this Gardu Pandang, visitors can see the natural beauty of Mount Merapi and Merbabu, as well as the expanse of agricultural land on both feet of the Mountain.

\section{RESPONDENTS DEMOGRAPHY CHARACTERISTICS}

Most of the respondents were women $(63,457 \%)$, in their productive age. They mostly worked as civil servants, entrepreneurs and labors. While tourist visitors in Ketep come from cities in Central Java such as the city of Semarang, Surakarta city and several other cities in Central Java. Respondents distribution can be seen in table 2 . 
Table 2. : Respondents Demography Characteristics

\begin{tabular}{llcc}
\hline $\begin{array}{c}\text { Respondent } \\
\text { Characteristics }\end{array}$ & \multicolumn{1}{c}{ Classification } & Total & $\%$ \\
\hline \multirow{2}{*}{ Gender } & Female & 158 & $63,45 \%$ \\
& Male & 91 & $36,55 \%$ \\
& $20-29$ & 61 & $24,50 \%$ \\
Age & $30-39$ & 63 & $25,30 \%$ \\
& $40-49$ & 65 & $26,10 \%$ \\
& $50-59$ & 41 & $16,47 \%$ \\
& $>60$ & 19 & $7,63 \%$ \\
& Students & 32 & $12,85 \%$ \\
Occupation & Civil Servants & 43 & $17,27 \%$ \\
& Private Employee & 24 & $9,64 \%$ \\
& Teachers or Lecturers & 35 & $14,06 \%$ \\
& Labors & 53 & $21,29 \%$ \\
& Entrepreneurs & 45 & $18,07 \%$ \\
& Armies & 17 & $6,83 \%$ \\
& 7 City and Magelang Regency & 76 & $30,52 \%$ \\
& Central Java & 55 & $22,09 \%$ \\
Origin & East Java & 32 & $12,85 \%$ \\
& Jakarta & 23 & $9,24 \%$ \\
& West Java, Banten & 25 & $10,04 \%$ \\
& Outside Java Island & 24 & $9,64 \%$ \\
& Overseas & 14 & $5,62 \%$ \\
\hline
\end{tabular}

Source : Processed Primary Data, 2018

\section{DESCRIPTIVE ANALYSIS}

Table 3 describes the results of pilot research testing to test the validity and reliability of data. The Cronbach Alpha coefficient for all variables is above 0.6 , meanwhile the validity coefficient is above 0.3 (DF: $30 ; a=0.05$ ), and the component coefficient of the matrix has 0.5 value, so the data can be stated as valid and reliable research data.

Table 3. : Pilot Research Test (30 Respondents)

\begin{tabular}{|c|c|c|c|c|}
\hline VARIABLES/INDICATORS & & $\begin{array}{c}\text { CRONBACH } \\
\text { ALPHA }\end{array}$ & VALIDITY & $\begin{array}{l}\text { COMPOSITE } \\
\text { SCORE }\end{array}$ \\
\hline Novel seeking tourist-based attractions & & 0,839 & - & - \\
\hline a. Sensanional events, & & - & 0,635 & 0,781 \\
\hline b. challenges and risks. & & - & 0,665 & 0,801 \\
\hline c. Related to new and unique thingsc. & & - & 0,622 & 0,761 \\
\hline $\begin{array}{l}\text { d. Unusual stimuli or surprises. } \\
\text { attractions and events. } \\
\text { e. New natural scenery }\end{array}$ & New & - & $\begin{array}{l}0,654 \\
0,640\end{array}$ & $\begin{array}{l}0,785 \\
0,778\end{array}$ \\
\hline
\end{tabular}




\begin{tabular}{lccc}
\hline \multicolumn{1}{c}{ VARIABLES/INDICATORS } & $\begin{array}{c}\text { CRONBACH } \\
\text { ALPHA }\end{array}$ & VALIDITY & $\begin{array}{c}\text { COMPOSITE } \\
\text { SCORE }\end{array}$ \\
\hline Service Quality : & 0,731 & - & \\
a. Hospitality & - & 0,727 & 0,595 \\
b. Responsive & - & 0,554 & 0,795 \\
c. Reliability & - & 0,643 & 0,834 \\
d. Responsibility & - & 0,610 & 0,738 \\
e. Tangibility & - & 0,621 & 0,839 \\
Image of tourism products: & 0,878 & & \\
a. The product is easy to know (Friendly) & - & 0,647 & 0,783 \\
b. It is authentic in nature (Naturally) & - & 0,734 & 0,840 \\
c. It is familiar with the minds of consumers & - & 0,569 & 0,700 \\
d. It is accessibile, and & - & 0,814 & 0,899 \\
e. It is unique and distinctive & - & 0,839 & 0,908 \\
Tourist satisfaction: & & & \\
a. Travel experience & 0,745 & & \\
b. Value of perceived satisfaction & - & 0,525 & 0,869 \\
c. Holistic memory & - & 0,700 & 0,678 \\
Revisiting Interest : & - & 0,682 & 0,808 \\
a. Saying positive things & 0,830 & - & - \\
b. Reffer Visit & - & 0,690 & 0,856 \\
c. Visit Preference & - & 0,661 & 0,837 \\
\hline
\end{tabular}

Source : Processed Primary Data, 2018

Table 4 describes the mean and standard deviation of the 5 variables studied. For novelty seeking-based tourist attraction variables (mean $=$ 7.26; standard deviation $=0.74$ ); Service quality variable (mean = 7.20; standard deviation $=0.59$ ); tourism product image variable $($ mean $=7.28 ;$ standard deviation $=$ $0.70)$; tourist satisfaction variables (mean $=7.52 ;$ standard deviation $=$ 0.58 ), and revisiting interest (mean $=7.28$, standard deviation $=0.70$ ).

Table 4 : Mean and Standard Deviation

\begin{tabular}{lcc}
\hline \multicolumn{1}{c}{ Variable } & Mean & Std. Dev. \\
\hline Novelty-seeking based tourist attraction & 7,26 & 0,74 \\
Service Quality & 7,20 & 0,59 \\
Tourism Product Image & 7,28 & 0,70 \\
Tourist Satisfaction & 7,52 & 0,58 \\
Revisiting Interest & 7,28 & 0,70 \\
\hline
\end{tabular}

Source : Processed Primary Data, 2018

\section{GOODNESS OF FIT TEST}

SEM testing using AMOS V.22.00 shows the results of Chi-Square $(203,306<156,51)$; Probability (0.112 5 0.05); GFI (Goodness of Fit) Index $=0.929 \geq 0.95$; AGFI (Adjusted Goodness of Fit Index) is $0.909 \geq$ 0.90; RMR (Root Mean Square Residual) is $0.023<0.1 ; \quad$ CFI
(Comparative Fit Index) is $0.989 \geq$ 0.95; Cmin / DF $1.129 \leq 2.00$ and RMSEA $0.023 \leq 0.08$. So it can be concluded that the resulting path model is declared fit because it is in the range of required value. Likewise, SEM assumption testing, that both multivariate and univariate data is normal. The data 
are free from multivariate and univariate outliers, and also free from multicollinearity and intersection. Furthermore, a variance extract and reliabilty are also carried out. The results of the analysis produce coefficients for all variables are above the expected cut of value of 0.7 and 0.5 .

Chart 2 : Full Model of Structural and Equation

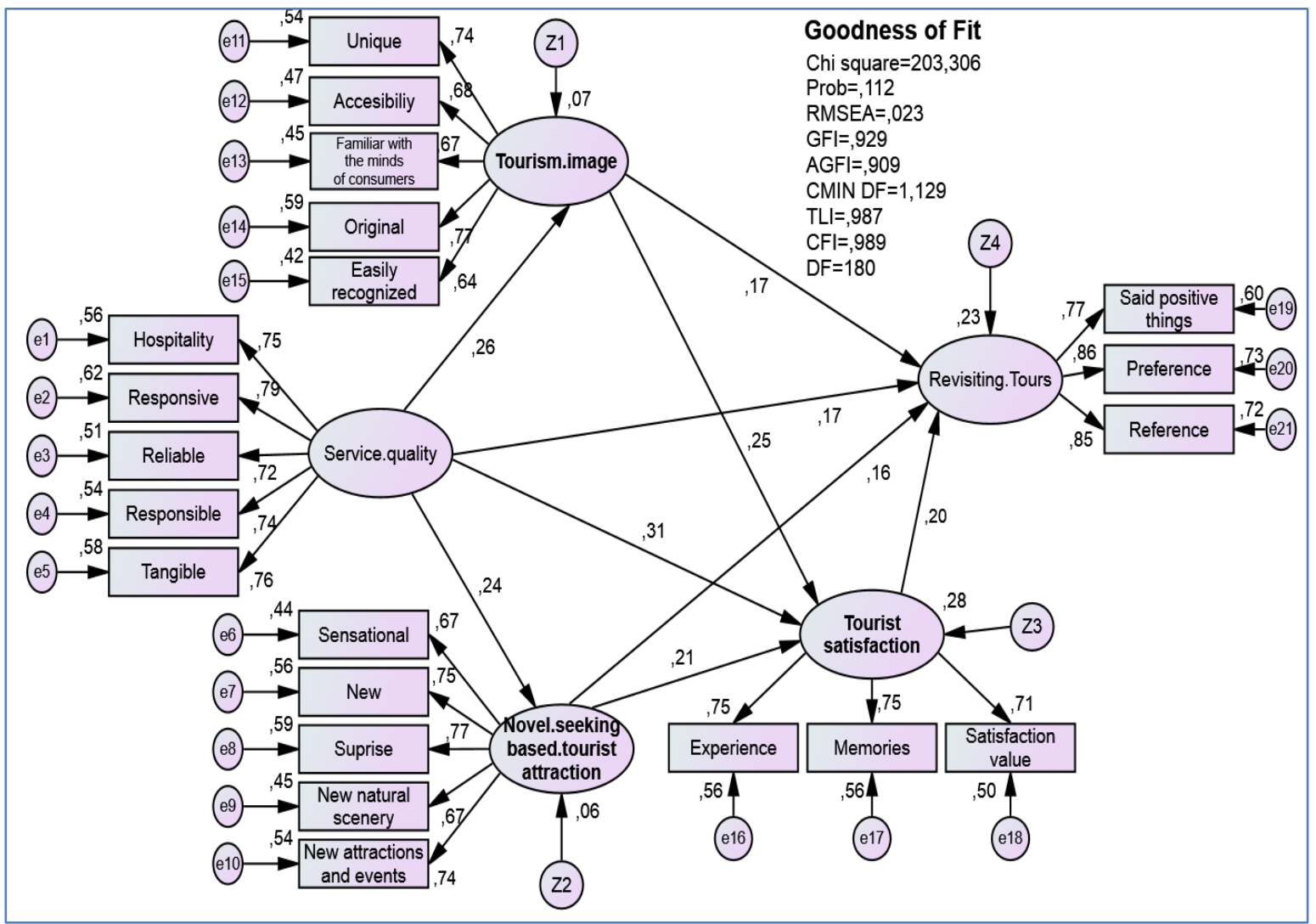

Source : Processed Primary Data, 2018

\section{HYPOTHESIS TEST}

Table 2 : Hypothesis Test

\begin{tabular}{|llrrrr|}
\hline & & Estimate & S.E. & C.R. & P \\
\hline 1. Service quality & $\rightarrow$ Tourist satisfaction & .298 & .076 & 3.931 & $* * *$ \\
\hline 2. Tourism image & $\rightarrow$ Tourist satisfaction & .349 & .112 & 3.118 & .002 \\
\hline 3. Service quality & $\rightarrow$ Revisiting tours & .153 & .069 & 2.227 & .026 \\
\hline 4. Service quality & $\rightarrow$ Daya tarik wisata \\
& berbasis novel seeking & .224 & .070 & 3.185 & .001 \\
\hline 5. Service quality & $\rightarrow$ Citra Produk & .179 & .053 & 3.379 & $* * *$ \\
\hline $\begin{array}{l}\text { 6. } \begin{array}{l}\text { Tourism Product } \\
\text { Image }\end{array} \\
\text { 7. Tourist satisfaction }\end{array}$ & $\rightarrow$ Revisiting tours & .224 & .103 & 2.180 & .029 \\
\hline
\end{tabular}




\begin{tabular}{|c|c|c|c|c|c|}
\hline & & Estimate & S.E. & C.R. & $P$ \\
\hline $\begin{array}{l}\text { 8. Novelty Seeking- } \\
\text { based Tourist } \\
\text { Attraction }\end{array}$ & $\rightarrow$ Tourist satisfaction & .209 & .080 & 2.606 & .009 \\
\hline $\begin{array}{l}\text { 9. Novelty Seeking- } \\
\text { based Tourist } \\
\text { Attraction }\end{array}$ & $\rightarrow$ Revisiting tours & .152 & .072 & 2.101 & .036 \\
\hline
\end{tabular}

Source : Processed Primary Data, 2018

\section{DISCUSSIONS}

Based on the parameters of the first hypothesis estimation, the variables of service quality on tourist satisfaction yields significant results $\left(\mathrm{CR}=3.931 ; \mathrm{p}={ }^{* * *}\right)$, with $\mathrm{a}$ significance level of 0.05 . This shows that the higher the quality of service, the higher the tourist satisfaction. This study is in accordance with the study (Crilley, 2005) that the quality of tourism services is directly dependent on hospitality, attractiveness of the location, local products and others. Rukuiziene (2009) explains that perceived service quality of tourism influences tourist satisfaction.

In the second hypothesis, the image variable of tourism products on tourist satisfaction shows significant results $(C R=3.118 ; p=$ 0.002 ), with a significance level of 0.05 . This shows that the higher the image of tourism products, the higher the satisfaction of tourists. This study supports Bosque and Martin (2008) that tourist satisfaction is formed from previous attitudes and beliefs, postexperience assessment, and future behavioral intentions and image. Those elements give significant role in satisfaction of visit.

The third hypothesis, between the variables of service quality to revisiting interest shows significant results $(C R=2.227 ; p=0.026)$, with a significance level of 0.05 . This shows that the higher the quality of service, the higher the interest in revisiting. This finding is in accordance with Tian-Cole et al. (2002). He states that the perception of service quality and satisfaction has proven to be a good predictor of visitors' future behavioral intention.

The fourth hypothesis, between service quality variables on novelty seeking-based tourist attraction shows significant results $(C R=3.185$; $\mathrm{p}=0.001$ ), with a significance level of 0.05 . This shows that the higher the quality of service, the better novelty seeking-based tourist attraction. Powel (2000) describes the principles of service attractiveness as an embodiment of excellent product quality, with very competitive prices and satisfying service.

In the fifth hypothesis, the variable Service Quality on Product Image shows significant results $(C R=$ 3.379; $\left.\mathrm{p}={ }^{* * *}\right)$, with a significance level of 0.05 . This shows that the higher the Quality of Service, the higher the Product Image. This study supports Dobni and Zinkhan (1990). They suggest that the definition of brand image is rational and emotional perception of a particular brand. Brand image arises based on consumer confidence in a particular brand both functionally and symbolically.

In addition, Park and Sinivasan (1994) state that in order to understand the brand image better, the unique characteristics of a product are urgent. A good product image is the main thing to determine the target market, the product 
position and explain the market response. The sixth hypothesis, between the image variable tourism products on high interest in revisiting shows significant results $(C R=2.180 ; p=0.029)$, with $a$ significance level of 0.05 . This shows that the higher the image of tourism products, the higher the interest in revisiting. Artuğer et al. (2013) mention that destination image influences tourist behavior such as intending to revisit and recommend it to others.

In the seventh hypothesis, the variables of tourist satisfaction on revisiting interest show significant results $(C R=2.251 ; p=0.024)$, with a significance level of 0.05 . This shows that the higher the tourist satisfaction, the higher the interest in visiting again. This result explains that repurchase interest of consumers to make purchases or encouragement that someone has to make a repeat purchase. Repurchase interest is part of buying behavior where in the context of repurchase interest there is a concept of loyalty (Solderlund and Vilgon, 1999). In addition, Fornell (1992) states that satisfied tourists will make repeat visits and inform others of the services they feel. Johnson (1998) says that information processes and satisfaction components together will be important elements in the repurchase cycle. Zeithalm et al (1996) emphasized that the importance of measuring customer repurchase intention (future intention) to determine the desire of customers who remain loyal or leaving an item and service. Similarly, Bosque and Martin (2008) find that tourist satisfaction is shaped by previous attitudes and beliefs, post-experience assessments, and behavioral intentions in the future. The results of his research also observed that image has a significant role in loyalty even though the relationship is not directly through the satisfaction of the results of the visit.

In the eighth hypothesis, the variables of novel seeking-based tourist attraction on tourist satisfaction show significant results $(C R=2.606 ; p=0.009)$, with $a$ significance level of 0.05 . This shows that the better the novel seekingbased tourist attraction, the higher the satisfaction of tourists. This is found by Spillane (2002), the attraction of tourism is things that attract the attention of tourists who are owned by a tourist destination. Oliver (1980) states that the impression of service quality received by customers influences the behavior of customers who come. The ninth hypothesis, among the variables of novel seeking-based tourist attraction towards high interest in revisiting shows significant results $(C R=2.101 ; \mathrm{p}=$ 0.036 ), with a significance level of 0.05 . This shows that the higher the attractiveness of novel seekingbased tourism, the higher the interest in revisiting. This finding supports (Crompton, 1979), and (Assaker et al., 2011) finding, that an important component in the motivation to travel is a new tourist attraction because it will give a good impression and will affect the interest in revisiting (Assaker et al., 2011) .

\section{CONCLUSIONS}

From the results of the analysis shows that good service quality will create a good image, but the image here cannot increase the revisiting interest. Because to increase revisiting interest, there is a direct influence that can be felt by tourists. Revisiting interest can be increased through tourist attraction that is driven by improved service quality. It can be concluded that 
good service quality is a vital capital for any tourist destination. Ketep Pass tourism object is good, but it still lacks in providing support facilities. However, service quality variables are proven to have a significant positive effect on revisiting interest.

\section{LIMITATIONS OF THE STUDY}

The limitation of this study is that there are two rejected hypotheses, namely the influence of tourist destination image on revisiting interest, and the tourist attraction has a very low effect on revisiting interest. Whereas, theorethically, a good tourist attraction will attract tourists' revisiting. For further study, there two issues that should be highlighted, (1) the eliminatation or replacement of variables with rejeceted hypotheses is needed and (2) it is necessary to add intervening or intermediate variables that have greater influence.

\section{REFERENCES}

Artuğer, S., Çetinsöz, B. C., \& Kiliç, I. (2013). The effect of destination image on destination loyalty: An application in Alanya. European Journal of Business and Management, 5(13), 124-136.

Assaker, G., Vinzi, V. E., \& O’Connor, P. (2011) Examining the effect of novelty seeking, satisfaction, and destination image on tourists' return pattern: A two factor, non-linear latent growth model. Tourism Management, 32(4), 890-901.

Baker, D. A., \& Crompton, J. L. (2000). Quality, satisfaction and behavioral intentions. Annals of tourism research, 27(3), 785-804.
Bigne, J. E., Sanchez, M. I., \& Sanchez, J. (2001). Tourism image, evaluation variables and after purchase behaviour: inter-relationship. Tourism management, 22(6), 607616.

Coban, S. (2012). The Effects of the Image of Destination on Tourist Satisfaction and Loyalty: The Case of Cappadocia. European Journal of Social Science, 29(2), 222-232.

Crompton, J. L. (1979). Motivations for Pleasure Vacations, . Annals of Tourism Research, 6(4), 408-424.

Faullant, R., Matzler, K., dan Fuller, J. (2008). The impact of satisfaction and image on loyalty: the case of Alpine ski resorts. Managing Service Quality, 18(2), 163-178.

Feng, R., \& Jang, S. (2004). Temporal destination loyalty: a structural initiation. Advances in Hospitality and Tourism Research, 9, 207-221.

Fornell, J. D., Michael, W, A., \& Eugene. 1996. The American Customer Satisfaction Index: Nature, Purpose and Findings. Journal of Marketing, 60, 7-18.

Kinnear, C, T., Taylor, \& R, J. (2003). Riset Pemasaran. Jakarta: Erlangga.

Kozak, M. (2000). A critical review of approaches to measure satisfaction with tourist destinations. Paper presented at the Tourism Analysis.

Lawson, F., \& Baud Bovy, M. (1977). Tourism and recreational development. London: Architectural press.

Mahasuweerachai, Patcharaporn, Qu, \& Hailin. (2011). The impact of destination image on value, satisfaction, and loyalty: Moderating effects of tourist characteristics and 
involvement. Paper presented at 16th Graduate student research conference, Amherst. Retrieved from http://scholarworks. umass.edu/ cgi/viewcontent.cgi? article $=1078 \&$ context

gradconf_hospitality.

Prayag, G., \& Ryan, C. (2011). Antecedents of Tourists' Loyalty to Mauritius: The Role and Influence of Destination Image, Place Attachment, Personal Involvement, and Satisfaction. Journal of Travel Research, 51(3), 342-356.

Rajesh, R. (2013). Impact of tourist perceptions, destination image and tourist satisfaction on destination loyalty: a conceptual model. Pasos: Revista de turismo y patrimonio cultural, 11(3), 67-78.

San Martín, H., \& Rodríguez, I. A. (2008). Exploring the cognitiveaffective nature of destination image and the role of psychological factors in its formation. Tourism Management, 29(2), 263-277.

Schiffman, L. G., \& Kanuk, L. L. (2007). Consumer behavior. London: Prentice Hall.

Söderlund, M., \& Öhman, N. 2003. Behavioral Intentions in Satisfaction Research Revisited. Journal of Consumer Satisfaction, Dissatisfaction and Complaining Behavior, 12, 53-66.
Tian-Cole, J., L, Crompton, \& Willson, V. L. (2002). An empirical investigation of the relationships between service quality, satisfaction and behavioral intentions among visitors to a wildlife refuge. Journal of Leisure Research, 34(1), 1-24.

Weiler, Betty, \& Colin. (1992). Spesial Interest Tourism. London: Bellhaven Pres.

Witt, F, S., \& Mountinho, L. (1994). Tourism Maketing and Management. Prentice Hall International.

Yoon, Y., dan Uysal, M. (2005). An examination of the effects of motivation and satisfaction on destination loyalty: A structural model. Tourism Management, 26(1), 45-56.

Zeithaml, V. A., \& Bitner, M. J., Gremler, D. D. (2009). Service marketing. Singapore: The McGrawHill Companies, Inc.

Zeithaml, V. A., L. L, Berry, \& Parasuraman. (1996). The Behavioral Consequences of Service Quality. Journal of Marketing, 60(2), 31-46.

Zuckerman, M., \& Kuhlman, D. M. 2000. Personality and risk-taking: common bisocial factors. Journal of personality, 68(6), 999-1029. 